\title{
Correction to: International interdependency of macroeconomic activities: a multivariate empirical analysis
}

\section{Sanjay Kumar Rout $^{1} \cdot$ Hrushikesh Mallick $^{1}$}

Published online: 25 September 2020

(C) Springer-Verlag GmbH Germany, part of Springer Nature 2020

\section{Correction to: International Economics and Economic Policy https://doi.org/10.1007/s10368-020-00483-1}

The correct name of the first author should be: Sanjay Kumar Rout

The publisher regrets this error.

The original article has been corrected.

Publisher's note Springer Nature remains neutral with regard to jurisdictional claims in published maps and institutional affiliations.

The online version of the original article can be found at https://doi.org/10.1007/s10368-020-00483-1

Sanjay Kumar Rout

sanjayrout1992@gmail.com

Hrushikesh Mallick

hrushi@cds.ac.in

1 Centre for Development Studies, Prasanth Nagar, Ulloor, Thiruvananthapuram,

Kerala 695011, India 